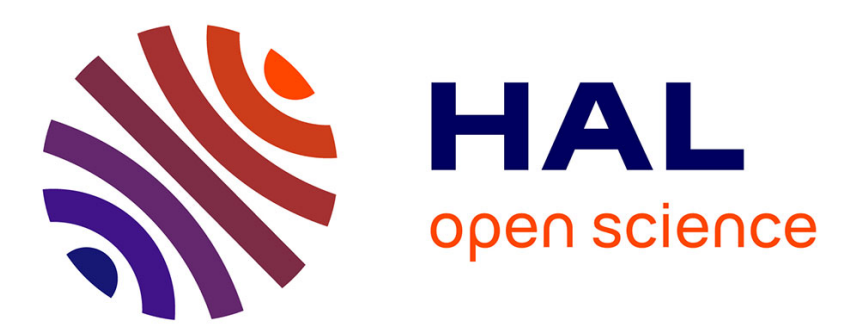

\title{
Revisiting and modelling the woodland farming system of the early Neolithic Linear Pottery Culture (LBK), 5600-4900 B.C
}

\author{
Mehdi Saqalli, Aurélie Salavert, Stéphanie Bréhard, Robin Bendrey, \\ Jean-Denis Vigne, Anne Tresset
}

\section{To cite this version:}

Mehdi Saqalli, Aurélie Salavert, Stéphanie Bréhard, Robin Bendrey, Jean-Denis Vigne, et al.. Revisiting and modelling the woodland farming system of the early Neolithic Linear Pottery Culture (LBK), 5600-4900 B.C. Vegetation History and Archaeobotany, 2014, 23 (Supplement 1), pp.37-50. 10.1007/s00334-014-0436-4 . hal-01354330

\section{HAL Id: hal-01354330 \\ https://hal-univ-tlse2.archives-ouvertes.fr/hal-01354330}

Submitted on 18 Aug 2016

HAL is a multi-disciplinary open access archive for the deposit and dissemination of scientific research documents, whether they are published or not. The documents may come from teaching and research institutions in France or abroad, or from public or private research centers.
L'archive ouverte pluridisciplinaire HAL, est destinée au dépôt et à la diffusion de documents scientifiques de niveau recherche, publiés ou non, émanant des établissements d'enseignement et de recherche français ou étrangers, des laboratoires publics ou privés. 


\title{
Revisiting and modelling the woodland farming system of the early Neolithic Linear Pottery Culture (LBK), 5600-4900 в.C.
}

\author{
Mehdi Saqalli · Aurélie Salavert · Stéphanie Bréhard • \\ Robin Bendrey $\cdot$ Jean-Denis Vigne $\cdot$ \\ Anne Tresset
}

Received: 2 July 2013/ Accepted: 18 January 2014

(C) Springer-Verlag Berlin Heidelberg 2014

\begin{abstract}
This article presents the conception and the conceptual results of a modelling representation of the farming systems of the Linearbandkeramik Culture (LBK). Assuming that there were permanent fields (PF) then, we suggest four ways that support the sustainability of such a farming system over time: a generalized pollarding and coppicing of trees to increase the productivity of woodland areas for foddering more livestock, which itself can then provide more manure for the fields, a generalized use of pulses grown together with cereals during the same cropping season, thereby reducing the needs for manure. Along with assumptions limiting bias on village and family organizations, the conceptual model which we propose for human environment in the LBK aims to be sustainable for long periods and can thereby overcome doubts about the PFs hypothesis for the LBK farming system. Thanks to a reconstruction of the climate of western Europe and the consequent vegetation pattern and productivity arising from it, we propose a protocol of experiments and validation procedures for both testing the PFs hypothesis and defining its eco-geographical area.
\end{abstract}

Communicated by W. Schier.

M. Saqalli ( $\square)$

CNRS (UMR 5602 GEODE) Maison de la Recherche de

l'Université du Mirail, 5, Allées A. Machado,

31058 Toulouse Cedex 1, France

e-mail: mehdi.saqalli@univ-tlse2.fr

A. Salavert · S. Bréhard - J.-D. Vigne · A. Tresset MNHN (CNRS UMR 7209 Archéozoologie, Archéobotanique),

55 rue Buffon - CP 56, 75005 Paris, France

R. Bendrey

Department of Archaeology, University of Reading,

Whiteknights, Reading RG6 6AH, UK
Keywords Farming system - LBK · Conceptual modelling $\cdot$ Crops and livestock integration

\section{Introduction}

The Linearbandkeramik Culture (LBK) was the earliest agropastoralist society to settle in central and northwestern continental Europe, between 5600 and 4900 B.C., bringing with it a fairly homogeneous material culture as well as stable architectural standards. Pottery typology indicates that its origin lies in the Balkan-Carpathian area, especially the late phase of the Starčevo complex. The LBK first expanded eastwards and westwards as far as Ukraine and the Rhine valley around 5400 в.C., before reaching the central Paris Basin around 5050 B.C. and Normandy after 5000 в.с. (Crombé Ph and Vanmontfort 2007).

Although the "LBK crop package" is well known, the LBK farming system is still under discussion. A shifting cultivation (SC) model has long been considered by numerous authors to be the best one to explain the spread of the Neolithic lifestyle into the wooded areas across Europe (Childe 1929; Boserup 1976; Mazoyer and Roudart 1997). Technical investment is low, with no ploughing, and it would have produced high yields, although a great deal of labour would have been needed to prepare the land for sowing. It is the most parsimonious model regarding the rarest resource, that of labour.

It has been accepted for a long time that a system of SC was practised by the first agro-pastoral societies of central and northwestern Europe (Bogucki and Grygiel 1993; Bogaard 2002), while the first alternative proposals for permanent cultivation go back to the early 1970s (Modderman 1971; Kruk 1973; Lüning 1980, 2000; Rowley- 
Conwy 1981). More recently, the analyses of several LBK weed assemblages have provided the most reliable evidence so far for the discussion of farming practices. It was found that the proportion of annual plants on LBK settlements is far beyond what could be expected for a SC farming system (Bogaard 2002, 2004; Bogaard and Jones 2007). This permanent field (PF) hypothesis implies higher labour input than in the slash and burn SC system, and yields would have been lower. It also implies more technical investment in the maintenance of long-term land fertility.

The purpose of this paper is therefore to:

- discuss the conditions in which a PFs farming system could have been sustainable in the LBK social and environmental context, in the light of available evidence,

- formalise the methodology we use for building a farming system model that fulfils the above conditions.

Solving this problem is equivalent to disproving one or other of the two models, SC and PF, if we hypothesise that only one farming system pattern was practised. The sustainability of any given model must be tested according to the demographic and agro-environmental conditions of LBK society across time and space. Thus, we propose to test the main model limitations:

- Did SC support the whole LBK population including densely populated sites? As formalised by the promoters of the SC hypothesis, Childe (1929), Boserup (1976) and Mazoyer and Roudart (1997), this system is limited by its major constraint, the need for a vast territory in which long rotation could occur, thereby limiting human density. In fact, according to Mazoyer and Roudart (1997, p. 113), the maximum density that such a system could support is 10 inhabitants $/ \mathrm{km}^{2}$. However, sites such as Langweiler 8 (Boelicke et al. 1988) and Vaihingen an der Enz (Krause 2003) persisted for a period of at least three centuries, with a permanent occupation of ca. 15 houses. If we roughly consider a maximum occupation of 8-10 people per house as proposed by Dubouloz (2008), or 5-7 people across the whole of the LBK territory according to Ebersbach and Schade (2004), these quite populated sites therefore had a population of 120 to 150 people, requiring an average area of 400-500 ha (Mazoyer and Roudart 1997). If we concede that the land was organised concentrically from the site, it implies that fields were at least $1.2 \mathrm{~km}$ from the settlement, quite a long distance for people living in wooded country with high land availability. This simple calculation allows us to question the ability of the SC system to maintain populations over the LBK period.
- Was the PF system stable enough in terms of long term soil conditions for the maintenance of adequately fertile fields? As formalised by Bogaard (2005) or Ebersbach and Schade (2004), this system appears threatened by its major constraint, the need to maintain fertility with manure-providing livestock (Bogaard et al. 2013), itself constrained by forage availability in the woodlanddominated temperate Europe of that time (Bogucki 1982).

Archaeobotanical and archaeozoological data provide evidence to preferentially select one of the two systems. This issue can therefore be solved by the use of present-day or well documented past agronomy, agroforestry and animal husbandry, albeit contextualised and adapted to our study. This requires the use of information from farming systems that have largely not integrated elements from the agricultural revolutions of the 17th century, namely fodderonly crops. Such mechanisms, practices, dynamics and rationalities are used by inference for integration into our modelling process.

The conceptualisation of the LBK farming system presented in this paper is a product of the reflections within the framework of the OBRESOC project, funded by ANR (Agence Nationale de la Recherche). This project attempts to simulate the expansion of LBK culture in temperate Europe and the farming system model set out here, establishes one of the key modules of this general OBRESOC simulation.

\section{Conceptualising a farming system and settlement}

\section{Composition of the cereal package}

The major crops which formed the basis of the LBK economy originated in the Near East, where domestication began during the 10th millennium в.c. (Fuller et al. 2011; Willcox and Stordeur 2012). The number of taxa of cultivated plants and weeds significantly decreased from the Near East to the west of the LBK culture diffusion area in the Paris Basin, through south-eastern Europe (Colledge and Conolly 2007; Coward et al. 2008), from ten crops in Bulgaria to five in central Europe (Kreuz et al. 2005). This was probably due to both climatic and technological factors. Indeed, the abandonment of Triticum aestivum/turgidum (free-threshing wheat), part of the Near East crop package and less difficult to dehusk than hulled wheat, could be explained by the fact that the glumes of hulled wheat provide a better protection to the grain in wet conditions (Colledge and Conolly 2007). Thus, the LBK farming economy can be seen as the product of the adaptation of plants to the central European environment, 
notwithstanding LBK specific agricultural practices. The crop package is quite homogeneous on the LBK territory. A difference can be pointed out in the major hulled wheat cultivated, which seems to have been $T$. monococcum (einkorn) east of the Rhine and T. dicoccum (emmer) west of the Rhine (Kreuz 2007; Salavert 2011). Furthermore, the access to arable land also seems to have been different at site level as shown by Bogaard et al. (2011) at Vaihingen, where various house groups cultivated areas at differing distances from the settlement.

The necessary components of the farming system

Following Mazoyer and Roudart (1997), we assume that any farming system requires three types of products for self-sufficiency, each of them already having been identified in the LBK Culture:

- A carbohydrate providing crop. Cereals are the major group of plants in temperate areas which can fulfil this requirement. Following Knörzer (1971), Bakels (1978, 2009), Kreuz (1992, 2007) and Salavert (2011), whose conclusions were based on archaeobotanical macroremains, we consider T. monococcum and T. dicoccum, a hulled wheat, as the main cereals in the LBK cropping system, Hordeum vulgare (barley) being rare and often considered as a weed (Kreuz 2007).

- A protein source. Along with meat and dairy products from livestock (Tresset and Vigne 2011), pulses are the sole plants that fulfil such a need. Archaeological evidence shows that Pisum sativum (pea) and Lens culinaris (lentil) are the legumes that have been regularly identified in the LBK crop complex. According to Döhle (1993), Arbogast et al. (2001), Schmitzberger (2009) and Kovačiková et al. (2012), four animal species were raised and eaten: cattle, sheep, goat and pig. The analyses of cattle and sheep/goat mortality profiles (Hachem 2011; Kovačiková et al. 2012) and of organic residues from LBK pottery (Salque et al. 2012) have shown that dairy products were also a component of the diet of LBK populations, at least in some regions.

- A textile fibre providing element. LBK sheep were probably not able to provide wool (Ryder 1992, 1993; Greenfield 2010), although their hair might have been used to make felt. Weavable threads could have been obtained from plants. The sole species which was likely to have been cultivated for that specific goal in the LBK context is Linum usitatissimum (flax), notwithstanding its use for oil production (Bakels 2009; Herbig and Maier 2011).

- Furthermore, all past and present rural societies of the world use narcotic plants. Papaver somniferum (opium poppy) was noticed in the remains assemblages of some
LBK sites, mostly those located in the westernmost part of this culture's territory (Knörzer 1971; Salavert 2010, 2011).

Farming sustainability proposals

Several apparently absolute constraints to the sustainability of a PF system may have been overcome thanks to nontechnological farming practices that were and/or are still used in Europe. We hypothesise that such innovations would have been a key element to maintaining sustainable fertility of PFs systems.

Before presenting them, one must note that LBK settlements, and therefore LBK fields, are mostly found on loess soils (Gronenborn 1999). As pointed out by Catt (2001), loess is among the most fertile soils of present-day Europe. Even if the long-lasting fertility of such soils has been questioned (Langohr 2001), one may assume that the ease of farming on loess is already an argument which explains this preferential choice. Assuming that settling on land with such soils was based on an agronomic and rational choice by the LBK settlers, the cultivation of crops can therefore be considered as a pro-sustainable fertility practice.

Beyond LBK site location, we have selected five prosustainability practices, as shown in Fig. 1. Several are supported by archaeological evidence, while others have not been invalidated, therefore allowing the use of certain assumptions until eventual field-based refutation.

1. Agronomically, cereals may be sown in autumn or in spring in the case of crop failure. Historical sources show that this practice was repeatedly observed and noted in Europe throughout history (Comet 1992). Meanwhile, weeds characteristic of both autumn and spring sowing have been noted in LBK archaeological remains, leading archaeobotanists to interpret these as evidence of an intensive farming system, although they may also be seen as evidence of an adaptable and risklimiting farming system (Bogaard et al. 2005). While weed assemblage results suggest that cereals were spring-sown east of the Rhine (Kreuz et al. 2005), Jacomet and Karg (1996) hypothesize an autumn-sown crop of $T$. dicoccum, based on wild emmer physiology. In fact, the weed flora is more influenced by crop practices than crop seasonality (Lundström-Baudais 1986; Bakels 2009).

2. "It is not known whether active manuring was already practised" (Bakels 2009, p. 39). The low fodder productivity of woodland pastures may be overcome by generalized pollarding or coppicing (Robinson and Rasmussen 1989; Slotte 2001; Thiébault 2005; Bernard et al. 2006; Torquebiau 2007). Such a practice may increase the fodder productivity of surrounding 
Fig. 1 Introducing soil fertilising \& food securing proposals for sustaining the LBK permanent fields farming system

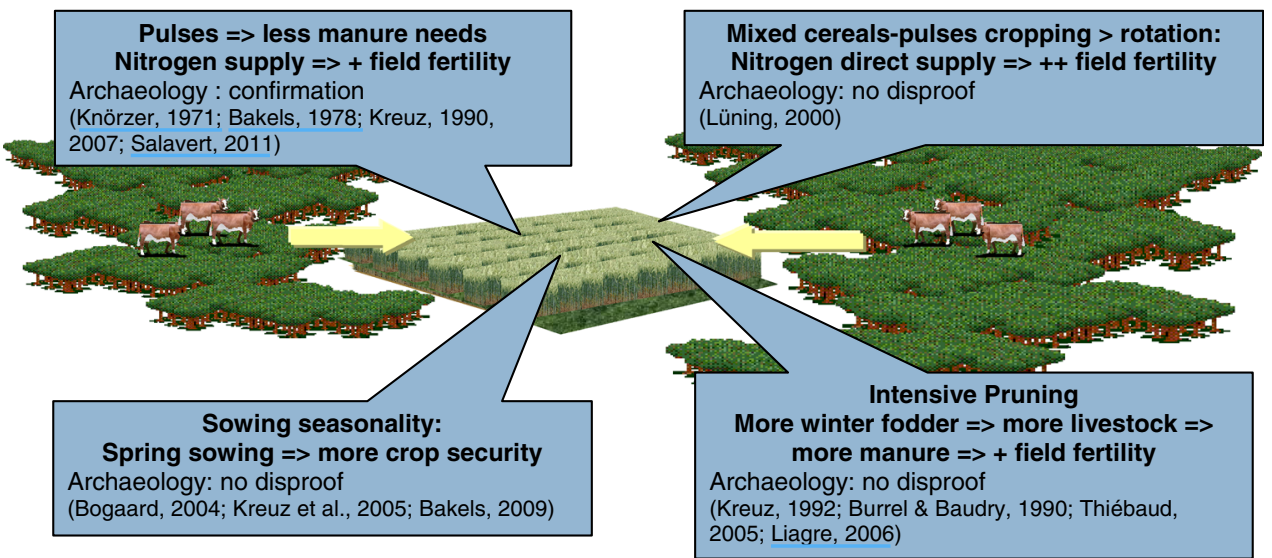

woodland by $60 \%$ (Von Carlowitz 1989), allowing a larger herd to survive winter and therefore to provide more manure for cultivated fields.

3. "Nothing is known of any form of letting land lie fallow" (Bakels 2009, p. 39). Considering that a soil cannot maintain its fertility without "modern" fertilisation processes leads to the dismissal of the PF system. A field that is managed, however, with a biennial rotation (cultivated 1 year followed by open field grazing followed by 1 year fallow) should keep its pro- "permanent fields" archaeobotanical assemblage. This fallow period may therefore help the field to recover, due to weed and grass cover growth and also to nocturnal herd-stalling with diurnal grazing/ browsing, thus creating fertility transfer from nearby woodland pastures (Bailloud 1975; Mazoyer and Roudart 1997). We have not considered the possibility of the use of dedicated fertility-recovering crops such as Trifolium (clover) or Medicago (lucerne), as this innovation did not spread to Europe until the Iron Age (Bouby and Ruas 2005).

4. "There is no indication of crop rotation including cereals and pulses to enhance fertility" (Bakels 2009, p. 39). As we have seen previously, cereals and pulses were cropped. Mixing them in the same fields for fertility and sowing optimisation purposes provides an easy means by which nitrogen can enable the recovery of soil fertility, thereby allowing a quicker recovery of vegetation cover during a 1 year fallow period. Whatever the crop succession management, legume production is a means by which soil can be enriched with nitrogen, thereby allowing long term stable cereal yields, if cereal density remains the same (Hillman 1981; Chorley 1981; Stopes et al. 1996; Pelzer et al. 2012).

5. Alternating pulses and cereals within the same field or mixing them does not have the same effect, since because of mineralisation, the fertility gain of legume cropping is reduced from 1 year to the next. However, this gain reduction is linked to temperature, and the reduction is far more important in tropical areas. This could explain why unmixed crops were more often observed in temperate areas. Meanwhile, mixing crops does have an effect on plant density so that two crops present in the same field may reduce the yield of each crop, unless the sowing density is indeed low. Considering that archaeological fields were planted in areas with very low populations (Dubouloz 2008) dominated by woodland as shown by the presence of Phleum pratense (Bakels 2009), the field density can be considered to have been very low. Due to low sowing density, we may consider that mixing pulses and cereals improves nitrogen-related fertility more than alternating them within the same field (Eichhorn et al. 2006; Malézieux et al. 2009). Such mixed cropping causes a decrease in the need for manure from livestock, thus reducing livestock requirements.

Reconstructing the farming cycle

According to the various proposals presented above, the PF system is believed to be both sustainable on the basis of evidence from present-day agronomy and zootechnics and consistent with available literature on archaeology (Lundström-Baudais 1986; Bogaard 2004; Kreuz 2007) and agronomy (Chorley 1981; Pelzer et al. 2012; Slotte 2001; Bonnefoy et al. 2001; Malézieux et al. 2009) for temperate Europe.

Agricultural work was certainly the most time-consuming activity for agro-pastoral communities during the Neolithic period. A holistic approach to the analysis of such farming systems is essential, however, in order to avoid independent assessment of individual components. The overall LBK system of land use should then be assumed to have included animal husbandry and predation 
Fig. 2 The calendar of production activities assumed for LBK populations

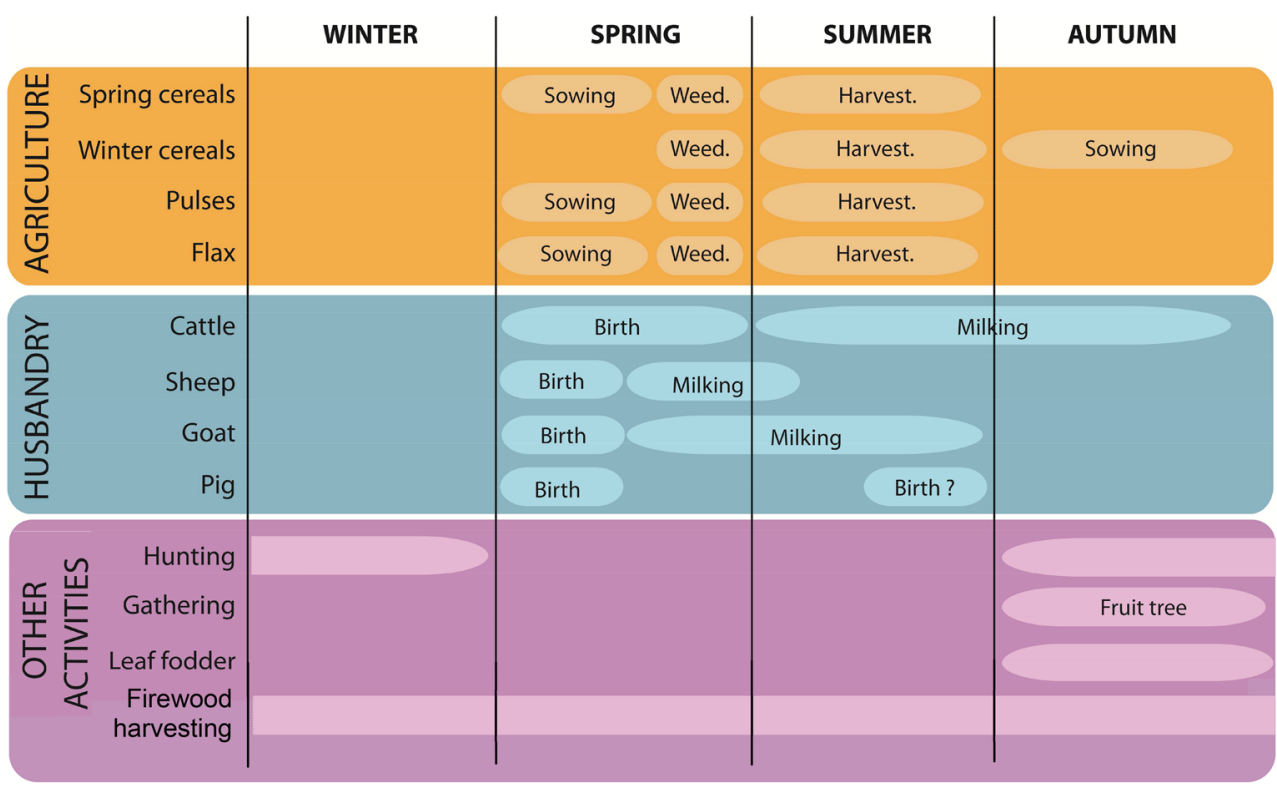

(hunting, gathering) alongside cultivation of crops. As a consequence, Fig. 2 presents all activities that comprise the PF production system of the LBK Culture, in a one-year cycle. This calendar illustrates that such a PF system would not have required much more input of labour than SC either at the annual level or at the seasonal level.

- The four crop suite (wheat, pulses, flax, garden vegetables) is considered to have been harvested during the summer (Bakels (2009). Wheat was sown in autumn, and in case of crop failure also in spring.

- Gathering is known for temperate Europe: it took place mainly at the end of the summer (apple, Salavert 2011; raspberry, Heim and Hauzeur 2002) and the beginning of autumn, when the gathering of hazelnuts and mushrooms can also be included (Salavert 2011).

- As there are few archaeological studies dealing with hunting seasonality during the LBK period, we have based the calendar of hunting activities on large game ethology as described by Hachem (2011) for instance, and on hunting representations as described by Hachem (1995, 2001). We assumed that hunting occurred mainly in two seasons, in the autumn, when game is still fat and when the deer are in herds together, and during the winter when vegetation is low and game is thus easier to detect.

- Finally, livestock keeping and firewood collection are activities that are practised throughout the year. Foddering animals implies leading them into glades, meadows and woodland pastures in spring, summer and autumn, and to fodder stocks in winter. In contexts later than LBK, in many low mountainous regions, plant macrofossils, pollen or insect assemblages indicate winter foddering (Rasmussen 1989, 1990, 1993; Haas and Schweingruber 1994; Overgaard-Nielsen et al. 2000; Delhon et al. 2008). Collecting sufficient winter leaf forage for animals could be achieved by storing fodder in settlements as well as "stock on the spot", with fodder collected and stored on tree branches in nearby woods, where livestock was present during the day.

\section{Building confidence in the model of the LBK PFs farming system}

Simulating the environmental module of the LBK landscape

In order to test the likelihood that such a farming system existed, production activities as described above must be set into a temporal cycle in order to compare the performance of the reconstructed farming system with temporally defined climatic cycles (seasonal as well as climate variations of the LBK era). Because LBK people settled in a vast area, the model must be adaptable to different environments within this area, for example plateaus and valleys, while excluding mountains and north-eastern areas.

For this purpose, the model must be location-dependant: human behaviour must be reconstructed upon spatial bedrock corresponding to temperate Europe with enough precision to enable the capturing of local dynamics and interaction between LBK communities and their landscape. These fundamental aspects have been modelled in the OBRESOC project, by D. Ertlen, D. Schwartz (Univ. 


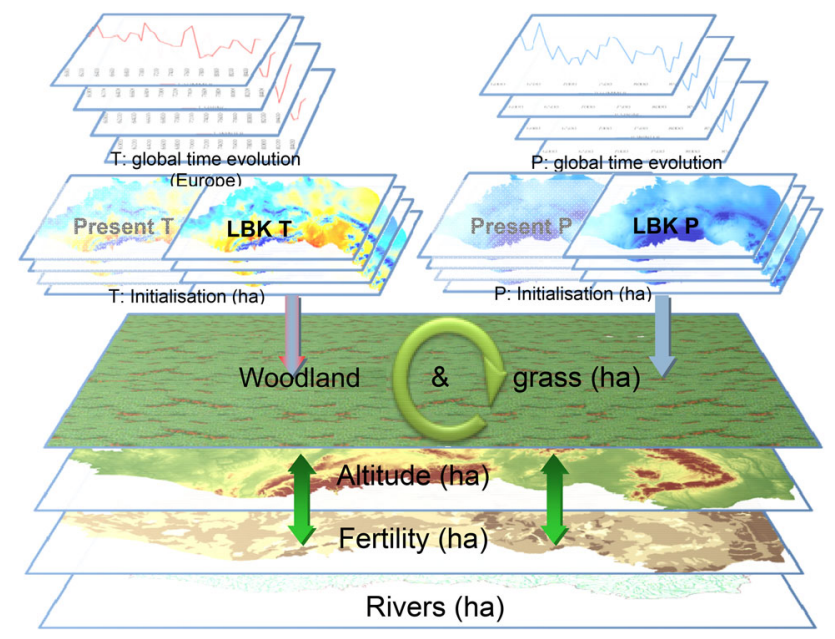

Fig. 3 Organisation of the "multiple layers" biophysical simulation for the model

Strasbourg) and J.-F. Berger (Cnrs/Univ. Lyon2) for pedology, and E. Ortu, M.-F. Sanchez-Goni (EPHE, Univ. Bordeaux1), R. Moussa (REEDS, UVSQ) and J.-F. Berger for climate, through different approaches (Bocquet-Appel et al. 2014b). These include soil retro-evolution methodology (Schwartz et al. 2011), palynology-based climate reconstruction (Ortu et al. 2011) and climate spatialization following the World Climate Project spatial variability (Hijmans et al. 2005). The integrated methods and results will be fully presented later by the authors (OBRESOC in progress). Here one could point out that there are more complex and exact modelling techniques (Lemmen et al. 2011; Kaplan 2012), but a procedure has been preferred where modelling phenomena details and sensitivity are limited to their significance towards the most important variable factors in the model, the impact of such a factor on human living conditions, but also where climate space and time intra-annual and inter-annual variability are both plausible for the LBK period and adequate for the settlement scale we use (Fig. 3).

The model should include the vegetation of the territory and its climate, including dynamic interactions between local soil and local vegetation that take into account local climate. In our agropastoral model, the estimation of vegetation for one portion of territory (for instance $1 \mathrm{ha}$ ) is based on palaeo-environmental remains (Kalis et al. 2003; Kreuz 2008; Salavert et al. in press) as well as composition and dynamics of present-day European semi-natural woodlands, of which Białowieża is the most prominent (Noirfalise 1984; Jedrzejewska et al. 1994; Ellenberg 2009). This estimation is translated into a forest ratio (F) ranging from $100 \%$, representing a full "climactic" forest, meaning a forest that may have reached its full theoretical development if local climate and soils remained
Table 1 Distribution of trees according to woodland types

\begin{tabular}{|c|c|c|c|c|}
\hline Trees & $\begin{array}{l}\% \text { in } \\
\text { riparian } \\
\text { woods }\end{array}$ & $\begin{array}{l}\% \text { in } \\
\text { other } \\
\text { woods }\end{array}$ & Fodder & References \\
\hline Quercus, oak & 10 & 50 & No & \multirow{9}{*}{$\begin{array}{l}\text { Robbe and } \\
\text { Gavaland } \\
(2006)\end{array}$} \\
\hline Fraxinus, ash & 40 & 25 & Yes & \\
\hline Ulmus, elm & 15 & 10 & No & \\
\hline Tilia, lime & 0 & 5 & Yes & \\
\hline Salix, willow & 0 & 5 & Yes & \\
\hline Betula, birch & 10 & 5 & No & \\
\hline Acer, maple & 10 & 0 & No & \\
\hline \multirow[t]{2}{*}{ Alnus, alder } & 15 & 0 & \multirow[t]{2}{*}{ Yes } & \\
\hline & 100 & 100 & & \\
\hline \multicolumn{5}{|l|}{ Underwood } \\
\hline Corylus, hazel & 0 & 30 & Yes & \multirow{12}{*}{$\begin{array}{l}\text { Kreuz (1992), } \\
\text { Kalis et al. } \\
\text { (2003), } \\
\text { Salavert } \\
\text { (2010), and } \\
\text { Noirfalise } \\
\text { (1984) }\end{array}$} \\
\hline Maloideae & 0 & 15 & No & \\
\hline $\begin{array}{l}\text { Other Rosaceae } \\
\text { (Prunus, etc.) }\end{array}$ & 10 & 10 & No & \\
\hline Betula & 0 & & No & \\
\hline Alnus & 25 & 0 & Yes & \\
\hline Acer & 15 & 20 & No & \\
\hline Fraxinus & 15 & 5 & Yes & \\
\hline Quercus & 0 & 5 & Yes & \\
\hline Hedera, ivy & 0 & 5 & Yes & \\
\hline Sambucus, elder & 0 & 5 & No & \\
\hline \multirow[t]{2}{*}{ Ulmus } & 35 & 5 & \multirow[t]{2}{*}{ Yes } & \\
\hline & 100 & 100 & & \\
\hline
\end{tabular}

constant, to $0 \%$ for grassland. The level of grassland is based on an equivalent reconstruction, meaning grassland can be fully developed (100\% grassland) or cleared $(0 \%)$. The "tree quantity" is split between underwood and full woodland. We assume a great simplification of the species distribution of trees, as described in Table 1.

Formalizing the social organisation of the LBK Culture

Ideas and concepts about this aspect of the general model have been discussed and debated during many OBRESOC workshops (OBRESOC, in progress). For the needs of our model we shall retain here, with differences, some of these ideas that directly concern the farming system itself.

We thereby consider a society based on non-nuclear households with independently owned land and herds. Herds may have been managed at the village level, while herd and land products may have been used exclusively by their owners following Todd (2011), who states that no agropastoral rural societies have ever settled in property collectives of land or livestock. Families, nuclear or included in enlarged households, are therefore the basic unit of our reconstruction. Families can evolve from nuclear to polynuclear organizations along the history of 
each family. Due to the lack of clear evidence to the contrary, we conceive a society with a limited level of hierarchy between households and between the nuclear family components of each household.

We then utilise non-cooperative households, a social household model that has the smallest impact on family evolution, and therefore the smallest probability of family accumulation of lands and livestock along generations (Perrot and Landais 1993; Gastellu and Dubois 1997; Chiappori and Donni 2006; Saqalli et al. 2013). A household can be composed of one or several nuclear families, where each member is linked with other members via duties and responsibilities, but where household members do follow the rationality of the head of the household, the eldest member of all the nuclear families that compose the household, only when crises occur such as family splitting or food crises. Several production activities may therefore have been taken on concurrently by different members of the household. As a consequence, each member of the family behaves in connection with another member, without the total subordination of any one member of the unit. The agricultural production of each specific family nuclear unit is considered to have been under the management of one sole head of that nuclear family, thereby enabling the assimilation of families as one homogeneous unit in terms of food production, and households as one homogeneous unit in terms of food consumption and social duties. The consequences of this structure could be vast, and would lead to a higher society-originated demography and greater assets for expansion alongside lower robustness in the face of environmental crises.

Finally, one should acknowledge the crucial importance of available labour resources in a context where land is abundant. Crop growth is therefore governed by the availability of labour along with rainfall and soil fertility. The expansion of family property is defined as being subject to the will of the family, according to its own growing needs but conditioned by its available resources.

\section{Setting the production activities of the LBK economy}

We assume the near impossibility for a farmer to have planned his or her whole process of crop cultivation along strictly rational lines, taking into account the series of potential factors that may cause damage to a crop. According to Fafchamps (1993) and Gavian and Fafchamps (1996), we cannot know with any certainty what rationale a villager may have pursued: maximisation, securitization and optimisation under constraints constitute different rationales that may have important modelling consequences at the European LBK level. For instance, choosing a maximisation process is known to induce modelled villagers to increase the manpower dedicated to farming beyond the ethnography-based position on farming
(Chayanov 1966; Saqalli et al. 2010), thus exposing them to higher climate-related risks.

A farming system settling in temperate Europe, a vast and nearly empty territory with less than 1 inhabitant $/ \mathrm{km}^{2}$, that can be considered similar in terms of space availability to the American West or to eastern Russia in the 19th century, is not primarily constrained by land. In fact, beyond the obvious land requirements necessary for agriculture, other activities beyond agriculture within the social and farming system, such as feeding livestock and firewood fetching must also be integrated into the model. These activities require greater areas of space than crop cultivation alone, and the products of these activities are vital.

\section{Cultivating cereals and pulses}

Each of the three stages of crop processing (sowing, weeding, harvesting) requires at least one week of work by a single person on a 1 ha parcel of land (Giampietro et al. 1993; Giampietro 1997), especially with the Neolithic tool set then available, which was most probably composed of digging sticks and adzes. To complete these successive stages, the implication is that the villager would mobilise all the available family manpower, calculated in Farming Labour Units (FLU; Fig. 4). In our case, female and male adult manpower is equivalent and equal to 1 . Child manpower capacity is predicated on age, so for a child $i$ in the village: Manpower (i) = Age (i)/20. We consider that one FLU can sow 130 pixels of one ha (not a constraint), weed 13 parcels and harvest 26 per one-season time step.

Cereal growth is affected by various factors that change with each stage of crop processing. At the sowing stage (in autumn and spring), the crucial factor is soil fertility, including the effect of manure, followed by temperature and rainfall. The weeding stage in spring is the main constraint along with rainfall and soil fertility, although the main limitation at the weeding stage is in terms of manpower. Harvests must also be gathered quickly before heavy rains. The crop cycle for pulses is simulated along the same processes of sowing, weeding, maturing and harvesting. Pulse parameters, however, obviously differ from those of cereals.

\section{Gardening}

Archaeobotany does not provide evidence for vegetable gardens. Even without such evidence, one may assume their existence as small plots that complemented cereal/ pulse "garden cultivation" fields as named by Bogaard (2005). These small vegetable plots are perceived to have been essential, as no self-sufficient farming system could have existed without them, as pointed out by Mazoyer and Roudart (1997). Two conditions are necessary to enable a villager to garden: family property with access to water and 
available labour. Vegetable gardening follows an equivalent sequence of actions to that of cereal farming.

\section{Livestock husbandry}

Theoretically, each family could own a herd of four possible livestock animals featured within the LBK Culture, cattle, sheep, goats and pigs, with the implication that livestock products remained within the family. However, herd management probably occurred at hamlet or settlement scale (Ebersbach and Schade 2004), rather than at household scale, given the minimum size required for a viable population, which is $30-50$ head for a cattle herd, following Dahl and Hjort 1976; Bogucki 1982; Gregg 1988; Ebersbach and Schade 2004). The maximum size of a domestic herd on the other hand, is linked to the carrying capacity of the territory, and this is less than one animal per person, following the land use model of Ebersbach and Schade (2004). In our model, each animal evolves according to its species, sex, age and food availability, using present-day data (Dahl and Hjort 1976; Digard 1981; Otte and Chilonda 2002; Clutton-Brock and Pemberton 2004). Each species is then characterised by its parameters regarding natural mortality, growth, reproduction, food requirements in terms of quantity and type (grass or trees) and productivity (meat, milk, hair).

Consumption of animal products is subject to zootechnical constraints and food consumption (milk and dairy products available during ruminant milking periods, meat from sacrificed animals for weddings or births, for example). Another major animal product is manure that is used to improve the soil. Following Ayantunde et al. (2000, 2002), half of the manure of one herd is spread in grazed areas as day time manure, while the other half remains in corrals at night and is then spread on the herd owner's fields.

\section{Livestock fodder}

For the farming system itself, and as livestock produces milk, meat and manure, we must calculate the necessary amount of land which would have been required to keep the settlement's herd alive throughout the year. This includes during the winter, when the livestock fodder sources may have depended on hay or leafy fodder stored from spring and summer. Fodder production is not only derived from surrounding open areas such as woodland glades, meadows and steppes, and crop residues such as straw and chaff but also from woodland areas where we assume LBK farmers practised coppicing and pollarding, as shown during slightly later and even contemporary periods in the Mediterranean area (Rasmussen 1989, 1990; Thiébault 2005). We have purposely built our model to characterise the variability of fodder production according to space (soil fertility variability, climate spatial variability, climate distribution) and time (seasonal variations, interannual variability) while excluding characterisation according to species distribution.

According to Rasmussen $(1989,1990)$, we assume that a leaf fodder-producing tree regardless of species produces on average $40-50 \mathrm{~kg}$ of leaves, and a coppiced tree may produce half this amount, $20-25 \mathrm{~kg}$. However, the leaves of one tree may only be harvested once every 4 years in order for the tree to recover. Moreover, the harvest is not total, as not all leaves are accessible. Therefore, we assume that one tree may provide $10-12.5 \mathrm{~kg}$ of leaves every 4 years, so one quarter of all the leaves of a standard tree

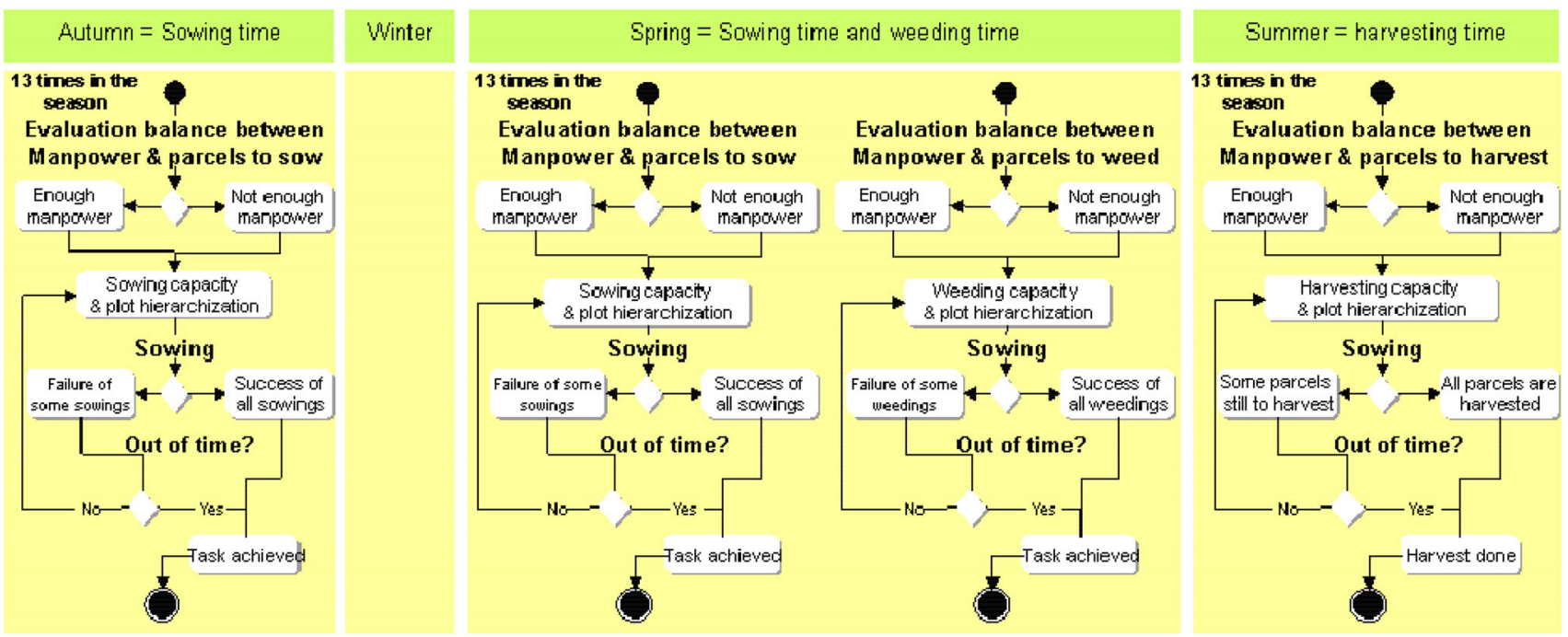

Fig. 4 Unified Modelling Language (UML) figures for the three successive labour-intensive steps in the cereal crop cycle, where each represents a sequence of evaluation and action 
and half of the leaves of a coppiced or pollarded tree. Tree fodder must be harvested before the winter. The resulting fodder is considered as having lost half of its nutritional value (Haas and Schweingruber 1994).

According to the forest ratio F, 1 ha of pollarded or coppiced woodland may produce the equivalent of $172 \mathrm{~kg}$ of fresh fodder. According to Mosimann and Stettler (2012), one head of cattle (or two small ruminants) needs $16 \mathrm{~kg}$ of leaf and other tree fodder per day; 1 ha of such type of woodland may feed one cow for 10.75 days. Feeding cattle during the 3 months of winter therefore requires 8.4 ha per head of cattle, a $60 \%$ higher productivity due to the use of pollarding or coppicing, compared to the average 12-15 ha/head of cattle (Adams 1975; Ebersbach 1999; Ebersbach and Schade 2004) and the 10 ha Ebersbach and Schade have used in their model.

\section{Firewood}

According to Mazoyer and Roudart (1997), the average annual need by an individual for firewood is $0.4 \mathrm{~m}^{3}$. Thus, as highlighted by Dubouloz (2008), an average LBK household with $8-10$ persons would have required $3.2-4 \mathrm{~m}^{3}$ per year. This value is also found in other sources in the literature, such as Lindroos (2011) or Ola (2011).We estimate that woodland can generate an average firewood production of easy to gather and relatively dry $10 \mathrm{~cm}$ wood pieces (Dufraisse 2008), of around $1 \mathrm{~m}^{3} / \mathrm{ha}$ per year (Marsinko et al. 1984). This value is highly variable depending on the environment, of course, whether it consists of valley, slope or plateau, for the average LBK settlement territory, and also the position of the settlement in Europe. The minimum area required to meet average LBK household needs is therefore 4 , or 0.4 ha per person.

\section{Hunting and gathering}

We calculate the quantity of non-timber forest products (NTFP) and fauna as a function of food per unit of surface, depending on the surface vegetation.

The following NTFP were considered: mixed berries, hazelnuts, apples, as witnessed by archaeobotany; fungi and snails were also likely to have been consumed. Each of these products is therefore roughly estimated as a function of the forest ratio F. For instance, according to Burmistov (1995), the presence of non-grafted wild apple trees is linearly linked to this ratio ( $1 \%$ of the trees of a full climax forest up to $21.5 \%$ for $\mathrm{F}=0.75$ until 0 when $\mathrm{F}=0$ ). Each wild apple tree can produce from 60 to $100 \mathrm{~kg}$ of fruit, but every 3 years, depending on the same ratio $\mathrm{F}$.

The quantity of hunted fauna has been estimated according to the same procedure. The following animals were considered: Cervus elaphus (red deer), Sus scrofa (wild boar), Bos primigenius (aurochs), Capreolus capreolus (roe deer), Equus caballus (wild horse), Bison bonasus (bison) and Alces alces (elk). All these game animals except wild boar are grouped into one herbivore class, while wild boar constitutes a single class of its own as the frequency with which it is found is inversely related to the forest ratio F. Table 2 shows the frequency values from Jedrzejewska et al. (1994,) and Okarma et al. (1995) for pristine forests $(\mathrm{F}=1)$ and exploited forests $(\mathrm{F}=0.5)$, based on the example of the Białowieża Primeval Forest, from which we estimated linear functions of frequency for $\mathrm{F}=0.1$ and $\mathrm{F}=0$. Based on the same references, the biomass is about $2,300 \mathrm{~kg} / \mathrm{km}^{2}$ for $\mathrm{F}=1$ and 1,250 $\mathrm{kg} / \mathrm{km}^{2}$ for $\mathrm{F}=0.5$.

\section{Validation and test procedures}

Next to the general programming of the OBRESOC project by R. Moussa (Bocquet-Appel et al. 2014a) and in attempt to test the specific hypotheses we are involved in, we built a local model using CORMAS software (www.cormas. cirad.fr), combining at the hamlet level ( 1 pixel $=1$ ha; hamlet model territory: $10 \mathrm{~km} \times 10 \mathrm{~km}$ ) local environment and related resources, with population socially organised in large families with the differing production activities of villagers having been assessed. Several procedures are to be followed to build confidence in the model and to enable the evaluation of the sustainability of both the PF and SC farming systems.

Testing the SC hypothesis using the duration of site occupation

The SC farming model hypothesis can be tested by estimating the ability of this farming system to meet food requirements once the population has exceeded a certain level. Our rough calculation suggests that although the limit can be easily reached, certain favourable conditions in Europe may have increased the "carrying capacity" of a $\mathrm{SC}$ site. We plan to apply this test to all temporally-defined LBK sites already in the database of the OBRESOC project. To that end, we hope to prove that no LBK site exists that can fulfil the conditions required for use of the SC system.

Testing the PFs against human resources constraints

The main constraint of the PF system as compared to SC is human resources. Fields must be sufficiently prepared for cultivation before sowing, and must then be weeded and 
Table 2 Frequency of wild game according to the forest ratio $\mathrm{F}$

\begin{tabular}{lllcr}
\hline & $\mathrm{F}=1$ & $\mathrm{~F}=0.5$ & $\mathrm{~F}=0.1$ & $\mathrm{~F}=0$ \\
\hline Herbivores & 63 & 76 & 95 & 100 \\
Wild boar & 37 & 24 & 5 & 0 \\
\hline
\end{tabular}

harvested. Livestock also needs to be fed by being sent into productive woodland throughout the year. Fodder must be collected and stored in summer and autumn for use during winter. The level of labour required implies sufficient people, thus several families supporting each other and/or enough people in each family. If this system collapses across all European temperate regions, then the manpower productivity cannot meet the requirements of the PF hypothesis, and so the possibility of such a farming system is ruled out. If this system collapses only in conditions found in areas where the LBK did not settle, confidence can be placed in the farming system constructed here.

Confirming the PF system using soil distribution of the LBK sites

Considering the variability in the productivity of soils which we obtained from present-day agronomy data, one may consider that the LBK population settled on sites based upon rational assessment. Therefore, if we analyse the proportions of the different soil types in LBK sites to see if they significantly differ from the average proportion of soil types in temperate Europe, it would show that the soil type was a key LBK criterion in the selection of settlement sites. Therefore, following for instance Lorz and Saile (2011), analysing the soils around sites may show that their proportion of good, mainly loess, soils our "best choice" hypothesis for the PF system, differs significantly from an average site in temperate Europe, thus providing confidence in our farming system reconstruction.

\section{Confirming the PF system using palaeo-bioclimatology}

The PF system does not seem to have been constrained by the availability of natural resources. The first constraint appears to be the quantity of woodland required for the feeding of livestock. Woodland foddering performance declines in conditions with cold and frost, implying that such a farming system could not have been used by a LBK population settled in mountainous and high plateau areas of the Alps, nor in the present-day plains of Belarus and Russia, or in Scandinavia. Discovering new LBK sites may thus enable the refutation of our farming hypotheses. Until then, modelling such a farming system and testing its consistency implies that its expansion is seen as being restricted to temperate Europe, therefore enabling the avoidance of less hospitable terrain during simulations.

Discriminating SC and PF using LBK demography and expansion dynamics

Coupling this settlement-level model with rules regarding family colonisation may provide the means by which confidence can be placed in the modelled farming system: indeed, all other things being equal, production activities determine food availability at settlement level and therefore LBK demography and the dynamics of its expansion. Using the LBK sites in the OBRESOC database again and selecting only the sites for which the period of occupation is known, such as Langweiler 8 (Boelicke et al. 1988) or Vaihingen an der Enz (Krause 2003), and assuming that they are representative of the total number of sites in the OBRESOC data set, thus enables the reconstruction of an approximate spatial chronology of the LBK occupation of temperate Europe. This chronology may then be compared to those resulting from alternative simulations of the model with the PF and SC systems. Comparing observed data and simulation results with these two hypotheses may help distinguish the scenario that best fits the results.

\section{Conclusions}

In this paper, we have developed a conceptual model of two different farming system hypotheses, that of SC and $\mathrm{PF}$, both of which have been reconstructed according to archaeological results. To do this, for each LBK production activity that has been recorded by archaeology (agriculture, animal husbandry and foddering, hunting, gathering, firewood collection), we have approximately reconstructed the functioning and quantification of its productivity according to archaeological data and, where data has been lacking, we have based our analyses on present-day data. We have also selected the social organisation of the LBK Culture, according to both archaeology and socio-anthropology, through which production activities have been assessed.

This approach can be seen as a procedural means by which the range of possibilities for these farming systems can be investigated, thereby testing the two hypotheses selected, as well as the range of implied impossibilities, enabling the refutation of these hypotheses. As a result of our analysis, we propose a solid process for the evaluation of the long-term sustainability of the PFs Hypothesis on the basis of agronomy and zootechnics. Indeed, we envisage a relatively similar process in creating a model that may distinguish different husbandry possibilities for LBK livestock, due to the fact that non-industrial herding practices 
may have less variability than non-industrial farming practices in their performance and can thus be more easily quantified.

Such a conceptual approach should be implemented and we advocate the use of models that fulfils the requirements of such an approach, with adequacy between the functioning of rules that connect spatial and social entities at the hamlet and LBK territory level.

As described by Huigen et al. (2006), local interactions between environment and society in past farming systems are fundamental to the global evolution of a population. It must be noted, however, that change in farming system organisation is not always linear and does not always involve and/or impact the whole population with the same intensity, thus creating social differentiation.

Distributive models include model processes that allow such combinations, through the programming of behaviour rules to numerous modelled entities called agents. In refining these rules, one can mimic various phenomena that are otherwise very difficult to copy and to understand. Multiple interactions between these entities can therefore be enabled and analysed. In reintroducing the time scale of events, such distributive models favour snowball effects and thus bring to light emerging phenomena, while highlighting the intrinsic inertia of all complex systems, including the ecological and social factors (Janssen and Ostrom 2006). Finally, and as described by Bousquet and Le Page (2004), distributive models are very easy to understand because they correspond to an intuitive conception of reality, which enables easier transcription across different software platforms.

Such models, including Agent-Based Models (ABM), are suitable for analysing farming systems (Saqalli et al. 2010), including those from the archaeological past (Kohler and van der Leeuw 2007). The low availability of quantitative data and the difficulty of launching statistically reliable investigations limit the use of statistical or multicriteria optimization models. This limit is due to the choice of the relevant unit, and also the required time, high cost and methodological difficulties that such investigations entail. ABMs allow a more flexible incorporation of partial results originating from different sources: palaeoclimatology, palaeopedology, bio-archaeology, family and social organization archaeology, agronomy and zootechnics, etc.

Admittedly, the LBK is, among the various Neolithic cultures, one of the most suitable ones for applying such an approach. A general lack of data is indeed inherent to the study of archaeology, although the LBK Culture is exceptionally well known and has been the subject of many investigations in various disciplines. One could therefore feasibly question the validity of extending our approach to other cultures where archaeological data is lacking, with reference to the parameterisation of the model.
Beyond the construction of this modelling tool which can be seen as a facility enabling experimentation, from a more thematic point of view this approach lets us reconsider our understanding of the farming systems of the first herders-farmers in temperate Europe. In particular, we question the commonplace idea that farming systems were strictly determined by various environmental constraints. In particular, by only considering the huge buffer effect of the availability of an incredibly vast territory per person, the hypothesis of an LBK collapse caused solely by environmental factors should be questioned.

Acknowledgments This research has been supported by the ANR project OBRESOC (Dir. J.-P. Bocquet-Appel) - A retrospective observatory of an archaeological society: the trajectory of the LBK Neolithic (convention ANR-09-CEP-004-01/OBRESOC). M. Saqalli, A. Salavert, S. Bréhard and R. Bendrey were funded by post-doctoral fellowships from this project. Parts of the scientific investigations on the OBRESOC project were conducted by MS as postdoctoral scientist and member of the International Centre REEDS at the Université Versailles St-Quentin-en-Yvelines.

\section{References}

Adams S (1975) Sheep and cattle grazing in the forests: a review. J Appl Ecol 12:143-152

Arbogast RM, Jeunesse C, Schibler J (2001) Rolle und Bedeutung der Jagd während des Frühneolithikums Mitteleuropas (Linearbandkeramik 5500-4900 v. Chr.) Internationale Archäologie: Arbeitsgemeinschaft, Symposium, Tagung, Kongress 1. Leidorf, Rahden/Westf

Ayantunde A, Williams TO, Udo HMJ, Fernandez-Rivera S, Hiernaux P, Van Keulen H (2000) Herders' perceptions, practice, and problems of night grazing in the Sahel: case studies from Niger. Hum Ecol 28:109-130

Ayantunde A, Fernandez-Rivera S, Hiernaux P, Van Keulen H, Udo HMJ (2002) Day and night grazing by cattle in the Sahel. J Range Man 55:139-143

Bailloud G (1975) Avant l'histoire. In: Duby G, Wallon A (eds) Histoire de la France rurale: Tome 1, La formation des campagnes françaises des origines à 1340. Seuil, Paris, pp $119-189$

Bakels C (1978) Four Linearbandkeramik settlements and their environment: a palaeoecological study of Sittard, Stein, Elsloo and Hienheim. Analecta Praehistorica Leidensia 11

Bakels C (2009) Heirs to the first farmers: 4900 B.c. -4300 в.c.: the western European loess belt. In: Bakels C (ed) The western European loess belt: agrarian history, 5300 B.C.-A.D. 1000. Springer, Berlin, pp 55-64

Bernard V, Renaudin S, Marguerie D (2006) Evidence of trimmed oaks (Quercus sp.) in north western France during the early Middle Ages (9th-11th centuries A.D.). In: Dufraisse A (ed) Charcoal analysis: new analytical tools and methods for archaeology. BAR Int Ser 1483, Archaeopress, Oxford, pp 103-108

Bocquet-Appel JP, Moussa R, Dubouloz J (2014a) Multi-agent modelling of the Neolithic LBK. In: Computers Applications \& Quantitative Methods in Archaeology, Paris, pp 22-25

Bocquet-Appel J-P, Dubouloz J, Moussa R, Berger J-F et al (2014b) Multi-Agent modelling of the Trajectory of the LBK Neolithic: a study in progress. In: Whittle A, Bickle P (eds) Early Farmers: 
the view from Archaeology and Science. Proc Prehist Soc Brit Acad, London

Boelicke U, Von Brandt D, Lüning J, Stehli P, Zimmermann A (1988) Der bandkeramische Siedlungsplatz Langweiler 8, Gemeinde Aldenhoven, Kreis Düren. (Rheinische Ausgrabungen 28) von Zabern, Darmstadt

Bogaard A (2002) Questioning the relevance of shifting cultivation to neolithic farming in the loess belt of Europe: evidence from the Hambach forest experiment. Veget Hist Archaeobot 11:155-168

Bogaard A (2004) Neolithic farming in central Europe. Routledge, London

Bogaard A (2005) 'Garden agriculture' and the nature of early farming in Europe and the Near East. World Archaeol 37: $177-196$

Bogaard A, Jones G (2007) Neolithic farming in Britain and central Europe: contrast or continuity? Proc Br Acad 144:357-375

Bogaard A, Jones G, Charles M (2005) The impact of crop processing on the reconstruction of crop sowing time and cultivation intensity from archaeobotanical weed evidence. Veget Hist Archaeobot 14:505-509

Bogaard A, Krause R, Strien H-C (2011) Towards a social geography of cultivation and plant use in an early farming community: Vaihingen an der Enz, south-west Germany. Antiquity 85: 395-416

Bogaard A, Fraser R, Heaton T, Wallace M, Vaiglova P, Charles MP, Jones G, Evershed R, Styring A, Andersen N, Arbogast R-M, Bartosiewicz L, Gardeisen A, Kanstrup M, Maier U, Marinova E, Ninov L, Schäfer M, Stephan E (2013) Crop manuring and intensive land management by Europe's first farmers. Proc Natl Acad Sci USA 110:12,589-12,594

Bogucki P (1982) Early Neolithic subsistence and settlement in the Polish lowlands. BAR Int Ser 150, Archaeopress, Oxford

Bogucki P, Grygiel R (1993) The first farmers of Central Europe: a survey article. J Field Archaeol 20:399-426

Bonnefoy J-L, Bousquet F, Rouchier J (2001) Modélisation d'une interaction individus, espace, société par les systèmes multiagents: pâture en forêt virtuelle. L'espace géographique 1:13-25

Boserup E (1976) Environment, population, and technology in primitive societies. Popul Dev Rev 2:21-36

Bouby L, Ruas M-P (2005) Prairies et fourrages : réflexions autour de deux exemples carpologiques de l'Âge du Fer et des Temps Modernes en Languedoc. Anthropozoologica 40:109-145

Bousquet F, Le Page C (2004) Multi-agent simulations and ecosystem management: a review. Ecol Mod 176:313-332

Burmistov L (1995) New crops and wild fruits and nuts in the USSR. In: ACOTANC-95 The sixth conference of the Australasian council on tree and nuts. Crops inc., Lismore

Burrel F, Baudry J (1990) Hedgerows network patterns in France. In: Zonnefeld J, Forman R (eds) Changing landscape, an ecological perspective, Springer, New York, pp 99-120

Catt J (2001) The agricultural importance of loess. Earth-Sci Rev 54:213-229

Chayanov A (1966) The theory of peasant economy. The American Economic Association, New York

Chiappori P-A, Donni O (2006) Les modèles non unitaires de comportement du ménage: un survol de la littérature. L'actualité économique 82:9-52

Childe VG (1929) The Danube in prehistory. Clarendon Press, Oxford Chorley G (1981) The agricultural revolution in northern Europe, 1750-1880: nitrogen, legumes, and crop productivity. Econ Hist Rev 34:71-93

Clutton-Brock T, Pemberton J (2004) Soay sheep. Dynamics and selection in an island population. Cambridge University Press, Cambridge

Colledge S, Conolly J (2007) A review and synthesis of the evidence for the origins of farming in Cyprus and Crete. In: Colledge $S$,
Conolly $\mathbf{J}$ (eds) The origins and spread of domestic plants in southwest Asia and Europe. Left Coast Press, Walnut Creek, pp 53-74

Comet G (1992) Le paysan et son outil: essai d'histoire technique des céréales. (Collection de l'École française de Rome 165) Ecole Française de Rome, Rome

Coward F, Shennan S, Colledge S, Conolly J, Collard M (2008) The spread of Neolithic plant economies from the Near East to northwest Europe: a phylogenetic analysis. J Archaeol Sci 35:42-56

Crombé P, Vanmontfort B (2007) The neolithisation of the Scheldt basin in western Belgium. Proc Br Acad 144:261-283

Dahl G, Hjort A (1976) Having herds: pastoral herd growth and household economy. Department of Social AnthropologyUniversity of Stockholm, Stockholm

Delhon, C, Martin L, Argant J, Thiébault S (2008) Shepherds and plants in the Alps: multi-proxy archaeobotanical analysis of neolithic dung from La Grande Rivoire (Isère, France). J Archaeol Sci 35:2,937-2,952

Digard J-P (1981) Techniques des nomades Baxtyâri d'Iran. Cambridge University Press, Cambridge

Döhle H-J (1993) Haustierhaltung und Jagd in der Linienbandkeramik: ein Überblick. Zschr Archäol 27:105-124

Dubouloz J (2008) Impacts of the Neolithic demographic transition on Linear Pottery Culture settlement. In: Bocquet-Appel J-P, BarYosef $\mathrm{O}$ (eds) The Neolithic demographic transition and its consequences. Springer, Berlin, pp 207-235

Dufraisse A (2008) Firewood management and woodland exploitation during the late Neolithic at Lac de Chalain (Jura, France). Veget Hist Archaeobot 17:199-210

Ebersbach R (1999) Modeling Neolithic agriculture and stockfarming at Swiss lake shore settlements-evidence from historical and ethnographical data. Archaeofauna: Int J Archaeozool 8:115-122

Ebersbach R, Schade C (2004) Modeling the intensity of linear pottery land use: an example from the Mörlener Bucht in the Wetterau Basin, Hesse, Germany. In: Ausserer KF, Börner W, Goriany M, Karlhuber-Vöckl L (eds) Enter the past: the E-way into the four dimensions of cultural heritage. CAA 2003. Conference Proceedings. BAR Int Series 1227, Archaeopress, Oxford, pp 337-348

Eichhorn M, Paris P, Herzog F, Incoll L, Liagre F, Mantzanas K, Mayus M, Moreno G, Papanastasis V, Pilbeam J, Pisanelli A, Dupraz C (2006) Silvoarable systems in Europe: past, present and future prospects. Agrofor Sys 67:29-50

Ellenberg H (2009) Vegetation ecology of central Europe (transl Strutt). Cambridge University Press, Cambridge

Fafchamps M (1993) Sequential labor decisions under uncertainty: an estimable household model of West-African farmers. Econometr $61: 1,173-1,197$

Fuller D, Willcox G, Allaby R (2011) Cultivation and domestication had multiple origins: arguments against the core area hypothesis for the origins of agriculture in the Near East. World Archaeol 43:628-652

Gastellu J-M, Dubois J-L (1997) En économie : l'unité retrouvée, la théorie revisitée. In: Pilon M, Locoh T, Vignikin E, Vimard P (eds) Ménages et familles en Afrique : approches des dynamiques contemporaines. Les Etudes du CEPED, Paris, pp 75-97

Gavian S, Fafchamps M (1996) Land tenure and allocative efficiency in Niger. Am J Agric Econ 78:460-471

Giampietro M (1997) Socio-economic constraints to farming with biodiversity. Agric Ecosyst Environ 62:145-167

Giampietro M, Bukkens SGF, Pimentel D (1993) Labor productivity: a biophysical definition and assessment. Hum Ecol 21:229-260

Greenfield H (2010) The secondary products revolution: the past, the present and the future. World Archaeol 42:29-54 
Gregg SA (1988) Foragers and farmers: population interaction and agricultural expansion in prehistoric Europe. University of Chicago Press, Chicago

Gronenborn D (1999) A variation on a basic theme: the transition to farming in southern central Europe. J World Prehist 13:123-210

Haas J-N, Schweingruber FH (1994) Wood anatomical evidence of pollarding in ash stems from the Valais, Switzerland. Dendrochron 11:35-43

Hachem L (1995) La représentation de la chasse dans les espaces villageois rubanés de la vallée de l'Aisne (France). Anthropozoology 21:197-205

Hachem L (2001) La conception du monde animal sauvage chez les éleveurs du Rubané. In: Arbogast R-M, Jeunesse C, Schibler J (eds) Rôle et statut de la chasse dans le Néolithique ancien danubien (5500-4900): Internationale Archäologie 1. Leidorf, Rahden, pp 91-111

Hachem L (2011) Le site néolithique de Cuiry-lès-Chaudardes-1. De l'analyse de la faune à la structuration sociale. Internationale Archäologie 120, Leidorf, Rahden

Heim J, Hauzeur A (2002) Paysage paléobotanique des sites du Rubané et du groupe de Blicquy à Vaux-et-Borset « Gibour » (Hesbaye, Belgique). Culture du blé nu et récoltes de pommes en contexte blicquien. Bull Soc Préhist Française 99:289-305

Herbig C, Maier U (2011) Flax for oil or fibre? Morphometric analysis of flax seeds and new aspects of flax cultivation in Late Neolithic wetland settlements in southwest Germany. Veget Hist Archaeobot 20:527-533

Hijmans R, Cameron S, Parra J, Jones P, Jarvis A (2005) Very high resolution interpolated climate surfaces for global land areas. Int J Climatol 25:1,965-1,978

Hillman G (1981) Reconstructing crop husbandry practices from charred remains of crops. In: Mercer RJ (ed) Farming practice in British prehistory. Edinburgh University Press, Edinburgh, pp 123-162

Huigen M, Overmars K, De Groot W (2006) Multiactor modeling of settling decisions and behavior in the San Mariano watershed, the Philippines: a first application with the MameLuke framework. Ecol Soc 11:12-23

Jacomet S, Karg S (1996) Ackerbau und Umwelt der Seeufersiedlungen von Zug-Sumpf im Rahmen der mitteleuropäischen Spätbronzezeit. In: (Die spätbronzezeitlichen Ufersiedlungen von Zug-Sumpf. 1: Die Dorfgeschichte). Kantonales Museum für Urgeschichte Zug, Zug, pp 198-368

Janssen MA, Ostrom E (2006) Empirically based, agent-based models. Ecol Soc 11:24-37

Jedrzejewska B, Okarma H, Jedrzejewski W, Milkowski L (1994) Effects of exploitation and protection on forest structure, ungulate density and wolf predation in Białowieża Primeval Forest, Poland. J Appl Ecol 31:664-676

Kalis A, Merkt J, Wunderlich J (2003) Environmental changes during the Holocene climatic optimum in central Europe-human impact and natural causes. Quat Sci Rev 22:33-79

Kaplan JO (2012) Integrated modeling of Holocene land cover change in Europe. Quat Int 279-280:235-236

Knörzer K-H (1971) Urgeschichtliche Unkräuter im Rheinland, ein Beitrag zur Entstehungsgeschichte der Segetalgesellschaften. Vegetatio 23:89-111

Kohler T, Van der Leeuw SE (2007) The model-based archaeology of socionatural systems. Oxbow, Oxford

Kovačiková L, Bréhard S, Šumberová R, Balasse M, Tresset A (2012) New insights into the subsistence and early farming from Neolithic settlements in Central Europe: archaeozoological evidence from the Czech Republic. Archaeofauna 21:71-97

Krause R (2003) Zum Abschluss der Grabungen 1994-2002 in der bandkeramischen Siedlung bei Vaihingen an der Enz, Kreis Ludwigsburg. Archäol Ausgr Bad-Württ 2002:34-39
Kreuz A (1990) Die ersten Bauern Mitteleuropas-eine archäobotanische Untersuchung zu Umwelt und Landwirtschaft der Ältesten Bandkeramik. Analecta Praehistorica Leidensia 23, University Press, Leiden

Kreuz A (1992) Charcoal from ten early Neolithic settlements in Central Europe and its interpretation in terms of woodland management and wildwood resources. Actualités Botaniques: Bulletin de la Société botanique de France 139:383-394

Kreuz A (2007) Archaeobotanical perspectives on the beginning of agriculture north of the Alps. In: Colledge S, Conolly J (eds) The origins and spread of domestic plants in southwest Asia and Europe. Left Coast Press, Walnut Creek, pp 259-294

Kreuz A (2008) Closed forest or open woodland as natural vegetation in the surroundings of Linearbandkeramik settlements? Veget Hist Archaeobot 17(1):51-64

Kreuz A, Marinova E, Schäfer E, Wiethold J (2005) A comparison of early Neolithic crop and weed assemblages from the Linearbandkeramik and the Bulgarian Neolithic cultures: differences and similarities. Veget Hist Archaeobot 14:237-258

Kruk J (1973) Studia Osadnicze nad Neolitem Wyzyn Lessoych. Ossolineum, Wroclaw

Langohr R (2001) L'anthropisation du paysage pédologique agricole de la Belgique depuis le Néolithique ancien-Apports de l'Archéopédologie. Etude et Gestion des Sols 8:103-117

Lemmen C, Gronenborn D, Wirtz KWA (2011) simulation of the Neolithic transition in Western Eurasia. J Archaeol Sci $38: 3,459-3,470$

Lindroos O (2011) Residential use of firewood in Northern Sweden and its influence on forest biomass resources. Biomass Bioenergy 3:385-390

Lorz C, Saile T (2011) Anthropogenic pedogenesis of Chernozems in Germany? A critical review. Quat Int 243:273-279

Lundström-Baudais K (1986) Etude paléoethnobotanique de la station III. In: Pétrequin P (ed) Les sites littoraux néolithiques de Clairvauxles-Lacs (Jura), I, Problématique générale, L'exemple de la station, III edn, Maison des sciences de l'homme, Paris, pp 311-392

Lüning J (1980) Getreideanbau ohne Düngung. Arch Korrbl $10: 117-122$

Lüning J (2000) Steinzeitliche Bauern in Deutschland: die Landwirtschaft im Neolithikum. Habelt, Bonn

Malézieux E, Crozat Y, Dupraz C, Laurans M, Makowski D, OzierLafontaine H, Rapidel B, De Tourdonnet S, Valantin-Morison M (2009) Mixing plant species in cropping systems: concepts, tools and models, a review. Agron Sust Dev 29:43-62

Marsinko APC, Phillips DR, Cordell HK (1984) Determining residential firewood consumption. Environ Man 8:359-365

Mazoyer M, Roudart L (1997) Histoire des Agricultures du monde, du néolithique à la crise contemporaine. Seuil, Paris

Modderman PJR (1971) Bandkeramiker und Wanderbauern. Arch Korrbl 1:7-9

Mosimann E, Stettler M (2012) Pâture des vaches laitières: Besoins en surface. Inf ADCF 4(2): 1

Noirfalise A (1984) Forests and forests stands in Belgium. Presses Agronomiques de Gembloux, Gembloux

Okarma H, Jedrzejewska B, Jedrzejewski W, Krazinski Z, Milkowski L (1995) The roles of predation snow cover, acorn crop, and man-related factors on ungulate mortality in Białowieża primeval forest, Poland. Acta Theriol 40:197-217

Ola L (2011) Residential use of firewood in Northern Sweden and its influence on forest biomass resources. Biomass Bioenergy 35:385-390

Ortu E, Sanchez-Goñi M-F, Milzer G, Giraudeau J (2011) Dynamique du climat en région nord-atlantique et ses effets sur l'Europe centrale lors de l'expansion du Néolithique Rubané (5750-4750 cal BC). $22^{\text {ème }}$ Symposium de l'Association de Palynologues de Langue Francaise (APLF), Paris 
Otte M, Chilonda P (2002) Cattle and small ruminant production systems in sub-Saharan Africa. A systematic review. Livestock Information Sector Analysis and Policy, FAO Agriculture Department, Roma

Overgaard-Nielsen B, Mahler V, Rasmussen P (2000) An arthropod assemblage and the ecological conditions in a byre at the Neolithic settlement of Weier, Switzerland. J Archaeol Sci 27:209-218

Pelzer E, Bazot M, Makowski D, Corre-Hellou G, Naudin C, Al Rifaï $\mathrm{M}$, Baranger E, Bedoussac L, Biarnès V, Boucheny P, Carrouée B, Dorvillez D, Foissy D, Gaillard B, Guichard L, Mansard M-C, Omon B, Prieur L, Yvergniaux M, Justes E, Jeuffroy M-H (2012) Pea-wheat intercrops in low-input conditions combine high economic performances and low environmental impacts. Eur J Agron 40:39-53

Perrot C, Landais É (1993) Comment modéliser la diversité des exploitations agricoles? Méthodes d'études en milieu paysan. Les Cahiers de la recherche-développement 33:24-40

Rasmussen P (1989) Leaf foddering of livestock in the Neolithic: Archaeobotanical evidence from Weier, Switzerland. J Dan Archaeol 8:51-71

Rasmussen P (1990) Leaf foddering in the earliest Neolithic Agriculture. Evidence from Switzerland and Denmark. Acta Archaeol 60:71-86

Rasmussen P (1993) Analysis of goat/sheep faeces from Egolzwil 3, Switzerland: evidence for branch and twig foddering of livestock in the Neolithic. J Archaeol Sci 20:479-502

Robbe V, Gavaland A (2006) Histoire et utilisations des arbres isolés : exemple du frêne. Arbres et Sciences 16:72-84

Robinson D, Rasmussen P (1989) Botanical investigations at the Neolithic lake village at Weier, North East Switzerland: Leaf hay and cereals as animal fodder. In: Milles A, Williams D, Gardner N (eds) The beginnings of agriculture. Association for Environmental Archaeology. BAR International series 496, Archaeopress, Oxford, pp 149-163

Rowley-Conwy P (1981) Slash and burn in the temperate European Neolithic. In: Mercer R (ed) Farming practice in British prehistory. Edinburgh University Press, Edinburgh, pp 85-96

Ryder M (1992) The interaction between biological and technological change during the development of different fleece types in sheep. Anthropozoology 16:131-140

Ryder M (1993) The use of goat hair. An introductory historical review. Anthropozoologica 17:37-46

Salavert A (2010) Le pavot (Papaver somniferum) à la fin du $6^{\text {ème }}$ millénaire av. J.-C. en Europe occidentale. Anthropobotanica 1:3-18

Salavert A (2011) Plant economy of the first farmers of central Belgium (Linearbandkeramik, 5200-5000 B.C.). Veget Hist Archaeobot 20:321-332
Salavert A, Bosquet D, Damblon F (in press) Natural woodland composition and vegetation dynamic during the Linearbandkeramik in north-western Europe (central Belgium, 5200-5000 B.c.) J Archaeol Sci. doi:10.1016/j.jas.2012.10.017

Salque M, Bogucki P, Pyzel J, Sobkowiak-Tabaka I, Grygiel R, Szmyt M, Evershed R (2012) Earliest evidence for cheese making in the sixth millennium B.c. in northern Europe. Nature 493:522-525

Saqalli M, Bielders C, Defourny P, Gérard B (2010) Simulating rural environmentally and socio-economically constrained multiactivity and multi-decision societies in a low-data context: a challenge through empirical agent-based modelling. J Artif Soc Soc Simul 13:2

Saqalli M, Bielders C, Defourny P, Gérard B (2013) Reconstituting family transitions of Sahelian western Niger 1950-2000: an agent-based modelling approach in a low data context. CyberGeo 634

Schmitzberger M (2009) Haus- und Jagdtiere im Neolithikum des österreichischen Donauraumes. Unpublished doctoral thesis. Universität Wien, Wien

Schwartz D, Ertlen D, Berger J-F, Davtian G, Bocquet-Appel J-P (2011) Développement agricole et fertilité: comment évaluer la paléo-fertilité des sols aux échelles de temps millénaires ? Quelques réflexions à partir d'une étude de cas: l'agriculture rubanée en Europe. In: Carpentier V, Marcigny C (eds) Des hommes aux champs II. Approche archéologique des économies agricoles, Caen

Slotte H (2001) Harvesting of leaf-hay shaped the Swedish landscape. Landsc Ecol 16:691-702

Stopes C, Millington S, Woodward L (1996) Dry matter and nitrogen accumulation by three leguminous green manure species and the yield of a following wheat crop in an organic production system. Agric Ecosyst Environ 57:189-196

Thiébault S (2005) L'apport du fourrage d'arbre dans l'élevage depuis le Néolithique. Anthropozoology 40:95-108

Todd E (2011) L'origine des systèmes familiaux Tome 1: l'Eurasie. Gallimard, Paris

Torquebiau E (2007) L'agroforesterie: des arbres et des champs. L'Harmattan, Paris

Tresset A, Vigne J-D (2011) Last hunter-gatherers and first farmers of Europe. CR Biol 334:182-189

Von Carlowitz P (1989) Agroforestry technologies and fodder production: concepts and examples. Agrofor Syst 9:1-16

Willcox G, Stordeur D (2012) Large-scale cereal processing before domestication during the tenth millennium cal BC in northern Syria. Antiquity 86:99-114 